\title{
Reni Eddo-Lodge. 2017. Why I'm No Longer Talking to White People about Race. London: Bloomsbury Publishing.
}

\section{Book review by}

\section{Izabella Anna Wódzka}

izabella.wodzka.16@ucl.ac.uk

$\mathrm{PhD}$ candidate

Film Studies at University College London

https://orcid.org/0000-0002-6049-1505

Izabella Wódzka is a $\mathrm{PhD}$ candidate in Film Studies at University College London, and her research is focused on the representations of minority groups, especially Gypsy, Roma, and Travellers, in contemporary European cinema. Her work is intersectional and draws on a range of disciplines and methods in the Humanities. Her background is in literatures, languages and cultures (MA in Scandinavian Studies and MSc in Translation Studies from the University of Edinburgh).

\section{Critical}

Romani Studies 
As an Eastern European migrant in London, I picked up Reni Eddo-Lodge's book to learn more about black history in Britain. I was excited to read a personal account of experiences and issues facing young black women in contemporary British society. As a white female immigrant from a less prosperous part of Europe, I have been at the receiving end of negative stereotypes: "Do you work as a cleaning lady?" is a question I have heard countless times, along with patronizing attitudes ("You're hardworking people who add to our economy so you can stay after Brexit."), and sometimes nothing less than unvarnished racism. Thus, to read another woman's account of belonging to a visible historically marginalized group was an important lesson and frankly a great read. The provocative title immediately gets a reaction and, as later on explained by Eddo-Lodge, does not mean she is unwilling to talk about race issues: she just wants to do it on her own terms.

In this award-winning book ${ }^{[1]}$ Eddo-Lodge provides a comprehensive overview of black history in Britain, intermingling historical facts with her own experiences and thoughts and details from the lives of black migrants. It is an emotionally charged insight into the life of the Black Minority Ethnic (BME) community in Britain, especially in the multicultural giant that is London. The book's first two chapters, Histories and The System, outline the history of African and Caribbean migration to the UK and the interconnected systems of power and race that still guide contemporary society. In her account, Eddo-Lodge does not shy away from pointing out rampant racism and xenophobia present since the onset of significant black migration to the country. Despite receiving many newcomers from former colonies and Commonwealth countries from the 1950s to the 1970s, Britain is depicted as an unwelcoming land that merely tolerated its black labour force. Societal change, such as the rise of migration, has brought about increased racial awareness and a shift toward more positive attitudes. Nevertheless, the author argues that, in spite of some superficial changes, systemic racism is embedded deeply in British society. She devotes an entire chapter to What is White Privilege?, delving into a complex notion that recently has underlined many debates about racism. The next chapter, The Fear of a Black Planet, starts with the now infamous speech by Enoch Powell in which he declared that "In this country in fifteen or twenty years' time, the black man will have the whip hand over the white man" (117). Eddo-Lodge skillfully points out contemporary examples of the eponymous fear of a black planet, citing her conversation with the politician Nick Griffin and the xenophobia prevalent in post-Brexit referendum UK. Chapters 5, The Feminism Question, deals with intersections of racism with other identity categories such as gender and economic background. The writer evaluates her own experiences as a member of feminist movements that did not take into account race and its implications for women of colour. She tackles the questions of subjectivity of black female bodies in media and culture, or lack of it thereof, the visibility of black feminists and their additions to the field of Feminist Studies. In Race and Class, issues of poverty and neglect in predominantly coloured areas come to the forefront, as well as the prevalent stereotype of working class as being mostly white. Gentrification, internal class divisions, and the struggles to reposition oneself on the social ladder dominate this part of the book. The closing chapter, There's No Justice, There's Just Us, provides not

1 Winner of Foyles Non-Fiction Book of the Year, Blackwell's Non-Fiction Book of the Year, winner of the Jhalak Prize, and longlisted for the Baillie Gifford Prize for Non-Fiction among others. 
only a neat summary of the destructive power of systemic racism but also puts forward ideas and propositions of how we can fight it. Eddo-Lodge encourages her readers to take action, to stop the blatant passivity in the face of racism, even if it is something as small "(..) as chipping away at the warped power relation in your workplace" (224).

Having said that, a lack of rigour in language use poses questions about what the author means by "immigrants" and "migration," sometimes limiting these words to include only minorities of colour, at other times mentioning other ethnicities and nationalities in passing. While minor, in the wider context of a highly mixed multi-identity Britain, it might seem imprecise or even exclusionary. Consequently, her reasoning of why she no longer talks about race to white people becomes repetitive, just scratching the surface and failing to gain a deeper understanding of the patterns of behaviour that govern it. She often relies on generalizations that tend to divide the society into two groups - people of colour and white people - reducing a complex situation into simplified binary elements. Navigating the narrative in which we essentialize and label certain groups is tricky and laden with boobytraps. It could be argued that Why I'm No Longer Talking to White People about Race inadvertently falls into such a trap, losing sight of the bigger picture, with its optics mostly aimed at the black community in London. The writer makes an effort to include other ethnic minorities and more recent European and Eastern European migration, but the issue remains unexplored and the idea of xeno-racism does not appear at all. The latter term is a relatively new concept, as explained by Liz Fekete (2001), who quotes A. Sivanandan: xeno-racism is

(...) a racism that is not just directed at those with darker skins, from the former colonial territories, but at the newer categories of the displaced, the dispossessed and the uprooted, who are beating at Western Europe's doors, the Europe that helped to displace them in the first place. It is a racism, that is, that cannot be colour-coded, directed as it is at poor whites as well, and is therefore passed off as xenophobia, a 'natural' fear of strangers.

In this broader understanding of racism with all its socio-political implications, it is hard not to think of members of the Gypsy, Roma, and Traveller (GRT) community, who even today are treated as third-class citizens. It was, therefore, disappointing not to find any mention of GRT communities, especially with the emergence of popular visual representations like Big Fat Gypsy Wedding which were stigmatizing and sensationalist. It would be worthwhile for Eddo-Lodge to take more time to explore the parallels between the experiences of various ethnic groups living in Britain and focus more on the shared traits rather than divisions among these various communities.

Overall, the book presents a convincing portrait of race issues in Britain, and it reads easily due to the author's writing and ability to weave together various narratives. It is a personal account of being Black, rooted in Eddo-Lodge's own experiences and stemming from her need to add to the existing debate, and as such, it naturally privileges the author's stance and point of view. It is neither meant to be a historical epigraph nor aims to be a study of racism in the UK (nor a Brexit analysis), and when read with an open mind it provides an invaluable account of xenophobia, migration history, and race politics in contemporary Britain. An extra chapter dedicated to xeno-racism, especially in the context 
of GRT people, would be a welcome addition in the future and would provide a more nuanced view of the race question. Scholars working within and across fields such as contemporary literature, race, and European studies will most certainly find this an inspiring read, and if wanting more, Eddo-Lodge has now launched a series of podcasts about race and racism in the UK.

\section{References}

Fekete, L. 2001. The Emergence of Xeno-Racism. London: Institute of Race Relations. http://www.irr.org.uk/news/the-emergence-of-xeno-racism. 